\title{
Nabokov as Translator: Passion and Precision
}

\section{Brian Boyd ${ }^{1}$}

I want to follow a number of themes: to look at the Russian-American writer Vladimir Nabokov as a translator, at why he could be such an extraordinary translator, and especially at Nabokov as a translator of verse, perhaps the most extreme and controversial verse translator ever. What can his theory and his practice suggest for translation theory, especially for translating poetry? How can Nabokov or any translator help those who don't know Russian to appreciate Alexander Pushkin, not only by universal consent the greatest of Russian poets but by equally common consent the most untranslatable of writers?

Why could Nabokov be such an exceptional translator? With his usual modesty, he said he had "a perfectly normal trilingual childhood": he read and wrote Russian, English and French by the time he was seven. By the time he was fourteen he had also read all of Tolstoy, all of Shakespeare, and all of Flaubert in the original languages. By the end of his career he had been called the greatest stylist ever in English prose, and the foremost stylist in Russian prose; and he also wrote for the best French literary magazines.

Nabokov had English nannies, a French governess, a series of private Russian tutors, and quadrilingual parents. But even with this handy linguistic leg-up, he had to read in translation to tackle Latin, Italian, Greek, and Spanish. He would read classics in translation only if he could have the original text on the facing page. As he once told a Japanese interviewer, who asked him what he thought of Japanese literature, "I don't trust translations," so he hadn't read Japanese. None of us can master all the languages worth reading for their literatures, from Sanskrit to Swahili: we all need translations.

Nabokov always had creative projects aplenty: fiction, poetry, plays, essays, memoirs, criticism, literary scholarship, scientific articles on butterflies. As light relief from composing novels he would compose world-class chess problems. But as well as being a writer and a sometime tennis and boxing coach, as well as being a

\footnotetext{
${ }^{1}$ Brian Boyd is known primarily as an expert on the life and works of author Vladimir Nabokov and on literature and evolution. He is University Distinguished Professor in the Department of English at the University of Auckland, New Zealand.
} 
scientist at Harvard and a professor at Stanford, Cornell and Harvard, Nabokov was also a dedicated and life-long translator, from English, French and German into Russian and from Russian into English and French.

In his own role as translator, Nabokov aimed not for the foothills but the peaks. He translated especially the greatest poem of modern Russia, Pushkin's novel in verse Evgeniy Onegin, which occupies a place in Russian literature something like the combined place of Chaucer and Shakespeare in English literature, and he translated the greatest poem of medieval Russia, Slovo o polku Igoreve, The Song of Igor's Campaign. His translation of Eugene Onegin, about 250 pages long, was surrounded with another 1500 pages of notes. The commentary has been called the best commentary ever made to a poem; and the translation, perhaps the best translation ever made of poem. Nabokov's English notes on this Russian poem have been translated into Russian for the sake of Russian scholars. His English translation of Pushkin's poem is so accurate that the best Dutch translation of Eugene Onegin so far derives not from Pushkin's Russian but only from Nabokov's English version, by someone with no Russian.

Nabokov also wrote to James Joyce asking if he could translate Ulysses into Russian-arguably the greatest novel of the twentieth century. He signed a contract to translate into English Leo Tolstoy's Anna Karenina, arguably the greatest nineteenthcentury novel, if not ever. Circumstances meant that he finished neither of these projects, but he started translating young and he continued to translate all his life. As a boy, like many young Russian lads, he was besotted with the Wild West stories of a now-forgotten nineteenth-century Irish-American novelist, Mayne Reid, but his enthusiasm led not just to games of daring with his cousin, but to translating, at the age of eleven, Mayne Reid's novel The Headless Horseman into French-not into French prose but into poetry, into the classical French verse form, the alexandrine. In his early twenties, his father bet him he couldn't translate Romain Rolland's novel Colas Breugnon, written in a highly playful and patterned and punning archaic French, and to win the bet, Nabokov translated the 230-page book. Then at 22, he translated Alice into Wonderland into Russian, in what has been rated the best translation into any language, with some of Lewis Carroll's two-way puns turning into three-way puns. In the early 1930s, he translated into Russian the prologue to 
Goethe's Faust and a couple of his favorite passages from his favorite literary work, Hamlet, which he considered translating in toto.

Translation helped turn him from a Russian writer into an English one. Living in the Russian emigration in Germany in the 1930s, he found the first English translation of one of his novels so bad that he translated a second himself, then rewrote from scratch in English the first novel translated, then another novel directly in English, although he was still also writing in Russian. When he moved to the US in 1940, he decided to renounce writing in Russian prose, to force himself to write English, but the best way for him to earn money as a writer was to translate from Russian. He translated poems by Pushkin, Lermontov, Tyutchev, and Fet, the greatest nineteenth-century Russian poets, and by his friend Vladislav Hodasevich, whom he thought the greatest of twentieth-century Russian poets. He found jobs in American universities teaching Russian, and translated more Russian poetry for his students. The impossibility of finding accurate enough translations of Eugene Onegin prompted him to undertake the task himself in the 1950s. Then in 1958 Lolita was published in America, shot to the top of the best-seller lists, and allowed him to retire. From that point on translations of his old Russian work were in demand, and he assigned the task to his son Dmitri, but provided the final polish himself: nine novels, four volumes of stories, one play, one volume of his poetry. He also checked translations of his work into French and German, and his wife learnt Italian in her sixties to check the translations of his poetry into Italian.

After his brother and his sister each tried their hand at translating Lolita into Russian, Nabokov decided to do the job himself: if even his family couldn't manage it, he couldn't trust anybody but himself. At the end of the English version of Lolita, Nabokov had written an afterword, which concludes:

None of my American friends has read my Russian books and thus every appraisal on the strength of my English ones is bound to be out of focus. My private tragedy, which cannot, and indeed should not, be anybody's concern, is that I had to abandon my natural idiom, my untrammelled, rich, and infinitely docile Russian tongue for a secondrate brand of English, devoid of any of those apparatuses - the baffling mirror, the black velvet backdrop, the implied associations and traditions-which the native illusionist, frac-tails flying, can magically use to transcend the heritage in his own way. 
Some of us native speakers of English or Newzild wouldn't mind being able to write English at that second-rate level. Interestingly, though, when he translated Lolita back into Russian, he found his remembered Russian not quite as magical as he had thought. In a new Postscript to the Russian translation, he wrote:

I so fervently stress to my American readers the superiority of my Russian style to my English that some Slavists might really think that my translation of Lolita is a hundred times better than the original, but the rattle of my rusty Russian strings only nauseates me now. The history of this translation is a history of disillusionment. Alas, that "wondrous Russian tongue" that, it seemed to me, was waiting for me somewhere, was flowering like a faithful springtime behind a tightly locked gate, whose key I had held in safekeeping for so many years, proved to be nonexistent, and there is nothing behind the gate but charred stumps and a hopeless autumnal distance.... [Rivers and Nicol 190]

Others have not been so disillusioned. One Russian, not a bad stylist in English himself, places "the Russian Lolita on the very top step of the frozen escalator of Russian masterpieces" (he wrote this in 1987, just as the escalator was about to clank into life again). ${ }^{2}$ Two Russian scholars compiled an English-Russian dictionary of Nabokov's Lolita, listing only the words that Nabokov had translated in ways other than any of the existing English-Russian dictionaries-and that usually mean better, more accurately or more vividly. The dictionary was two hundred pages long, the novel itself, three hundred.

It's especially Nabokov the translator not of himself but of others, and not of prose but of poetry, that I want to talk about. On a number of occasions during his last twenty years Nabokov planned to collect in one volume his translations of other Russian poets, but he died before he could do so. That project saw the light more than thirty years later, when I edited with a young Russian colleague a volume published last year: Nabokov's Verses and Versions, as I called it: Three Centuries of Russian Poetry.

Translation of literary prose can be hard enough, as Nabokov found even in translating himself into his own native language, but translation of verse, especially rhymed verse, can be almost impossible. All the verse Nabokov translated in his Eugene Onegin and in Verses and Versions was rhymed. And here's where the

\footnotetext{
2 Barabtarlo Nabokovian 18
} 
controversy starts. Do you try to match the rhymes in the source language in the target language, or do you try to translate the exact sense of the source poem in your translation? Nabokov began his career translating rhymed poetry into rhymed poetry, and he did it superbly well, sometimes with almost perfect match of sense as well as of rhymes. ${ }^{3}$

\footnotetext{
${ }^{3}$ [[Let me give you just one sample, Nabokov's 1941 translation of Hodasevich's poem "Orpheus," where the man whose lyre becomes an image of poetic inspiration:
}

Orpheus

Brightly lit from above I am sitting in my circular room; this is Ilooking up at a sky made of stucco, at a sixty-watt sun in that sky.

All around me, and also lit brightly, all around me my furniture stands, chair and table and bed — and I wonder sitting there what to do with my hands.

Frost-engendered white feathery palmtrees on the window-panes silently bloom; loud and quick clicks the watch in my pocket as I sit in my circular room.

Oh, the leaden, the beggarly bareness of a life where no issue I see!

Whom on earth could I tell how I pity my own self and the things around me?

And then clasping my knees I start slowly to sway backward and forward, and soon I am speaking in verse, I am crooning to myself as I sway in a swoon.

What a vague, what a passionate murmur lacking any intelligent plan; but a sound may be truer than reason and a word may be stronger than man.

And then melody, melody, melody blends my accents and joins in their quest, and a delicate, delicate, delicate pointed blade seems to enter my breast.

High above my own spirit I tower, high above mortal matter I grow: subterranean flames lick my ankles, past my brow the cool galaxies flow.

With big eyes - as my singing grows wilder with the eyes of a serpent maybe, I keep watching the helpless expression of the poor things that listen to me. 
But when he began to teach Russian literature in American colleges, he came to decide that translating rhymes into rhymes was a criminal procedure: it necessitated inaccuracies, it required deviations from the original, it put into the original poet's mouth phrases he had never dreamed of. It left the student who knew a smattering of Russian befuddled and the student who knew no Russian in the dark as to whether this or that image or detail was the poet's or the translator's. ${ }^{4}$ Nabokov became an ardent champion of literal translation, and an ardent foe of rhymed translation.

In his Foreword to his 4-volume Eugene Onegin Nabokov launches straight into his mature theory of verse translation:

Can Pushkin's poem, or any other poem with a definite rhyme scheme, really be translated? To answer this we should first define the term "translation." Attempts to render a poem in another language fall into three categories:

(1) Paraphrastic: offering a free version of the original, with omissions and additions prompted by the exigencies of form, the conventions attributed to the consumer, and the translator's ignorance. Some paraphrases may possess the charm of stylish diction and idiomatic conciseness, but no scholar should succumb to stylishness and no reader should be fooled by it.

(2) Lexical (or constructional): rendering the basic meaning of words (and their order). This a machine can do under the direction of an intelligent bilinguist.

(3) Literal: rendering, as closely as the associative and syntactical capacities of another language allow, the exact contextual meaning of the original. Only this is true translation.

\footnotetext{
And the room and the furniture slowly, slowly start in a circle to sail, and a great heavy lyre is from nowhere handed me by a ghost through the gale.

And the sixty-watt sun has now vanished, and away the false heavens are blown: on the smoothness of glossy black boulders this is Orpheus standing alone.
}

Not bad,]]

${ }^{4}$ [[("In my circular room," in that translation, for instance, is not Hodasevich's image, but only Nabokov's way of rhyming with "bloom.")]] 
Let me give an example of each method. The opening quatrain of Eugene Onegin, transliterated and prosodically accented, reads:

Moy dyádya sámïh chéstnïh právil,

Kogdá ne v shútku zanemóg,

On uvazhát' sebyá zastávil,

I luchshe vïdumat' ne mog...

This can be paraphrased in an infinite number of ways. For example:

My uncle, in the best tradition,

By falling dangerously sick

Won universal recognition

And could devise no better trick ...

The lexical or constructional translation is:

My uncle [is] of most honest rules [ : ] when not in jest [he] has been taken ill, he to respect him has forced [one], and better invent could not ...

Now comes the literalist. He may toy with "honorable" instead of "honest" and waver between "seriously" and "not in jest"; he will replace "rules" by the more evocative "principles" and rearrange the words to achieve some semblance of English construction and retain some vestige of Russian rhythm, arriving at:

My uncle has most honest principles when he was taken ill in earnest, he has made one respect him and nothing better could invent.

And if he is still not satisfied with his version, the translator can at least hope to amplify it in a detailed note. ... .

(Let me digress here back into my own voice: if this doesn't sound to you like a great beginning to a great poem, this proves one of my points: Pushkin is the least translatable of poets. But all the same I hope you'll feel before I'm through that you've seen evidence he's a great poet. Now back to Nabokov's voice): 
We are now in a position to word our question more accurately: can a rhymed poem like Eugene Onegin be truly translated with the retention of its rhymes? The answer, of course, is no. To reproduce the rhymes and yet translate the entire poem literally is mathematically impossible. But in losing its rhyme the poem loses its bloom, which neither marginal description nor the alchemy of a scholium can replace. Should one then content oneself with an exact rendering of the subject matter and forget all about form? Or should one still excuse an imitation of the poem's structure to which only twisted bits of sense stick here and there, by convincing oneself that in mutilating its meaning for the sake of a pleasure-measure rhyme one has the opportunity of prettifying or skipping the dry and difficult passages? I have been always amused by the stereotyped compliment that a reviewer pays the author of a "new translation." He says: "It reads smoothly." In other words, the hack who has never read the original, and does not know its language, praises an imitation as readable because easy platitudes have replaced it in the intricacies of which he is unaware. "Readable," indeed! A schoolboy's boner mocks the ancient masterpiece less than does its commercial poetization, and it is when the translator sets out to render the "spirit," and not the mere sense of the text, that he begins to traduce his author.

In transposing Eugene Onegin from Pushkin's Russian into my English I have sacrificed to completeness of meaning every formal element including the iambic rhythm, whenever its retention hindered fidelity. To my ideal of literalism I sacrificed everything (elegance, euphony, clarity, good taste, modern usage, and even grammar) that the dainty mimic prizes higher than truth. Pushkin has likened translators to horses changed at the posthouses of civilization. The greatest reward I can think of is that students may use my work as a pony. (EO I.vii-x)

Nabokov was throwing down a gauntlet, and there was no shortage of people ready to take it up. The publication of Nabokov's Eugene Onegin in 1964 led to the fiercest feud about literary translation in the twentieth century, with distinguished figures pitching in from both sides of the Atlantic: Edmund Wilson, Robert Lowell, Anthony Burgess, and others, some attacking Nabokov, some supporting him. 
Nabokov's reaction to the challenges was to revise his translation in the direction of even stricter literalism. He wrote this in his introduction to the revised edition:

In an era of inept and ignorant imitations, whose piped-in background music has hypnotized innocent readers into fearing literality's salutary jolts, some reviewers were upset by the humble fidelity of my version; the present improvements will exasperate them even more. (EO I.xiii)

You might expect translators would be mild-mannered, studious types who can just lift a heavy dictionary but couldn't hurt a fly: and the people who invited me here seem not to have blood dripping from their fangs and claws. But translators can get very fierce about different principles of translation.

Pushkinist Alexander Dolinin writes that "Everyone who has tried to teach Eugene Onegin in rhymed translations knows all too well that they make it a futile enterprise to convince even the most gullible students that Pushkin, to quote Edmund Wilson, "is the only modern poet in the class of Shakespeare and Dante.",5 But Douglas Hofstadter, writing two years later in his Le Ton beau de Marot: In Praise of the Music of Language, saw translating rhymed verse without rhyme as a betrayal. In his book he demonizes "the rabid Nabokov," "the devil," "the implacably Nazistic Nabokov," for his "unrelenting verbal sadism" and "hardball savaging" that "goes way beyond bad taste." 6 Nabokov in reply might have quoted his "Problems of Translation: Onegin in English": "To translate an Onegin stanza does not mean to rig up fourteen lines with alternate beats and affix to them seven jingle rhymes starting with pleasure-love-leisure-dove. Granted that rhymes can be found, they should be raised to the level of Onegin's harmonies."

Before I go on to explain Nabokov's attitude to translating rhymed verse, and to show how I think it can work at its best, I want to stress how paradoxical his attitude is. Nabokov insisted on freedom as much as anyone ever has. He was an implacable foe of Soviet Russia and Nazi Germany and any dictatorship: one of his books is called Tyrants Destroyed. When an interviewer asked him for his three most important principles, he answered: "To be kind, to be proud, to be fearless." But as a translator he was happy, as he put it, to choose "the servile path." He's echoing and replying to Sir John Denham, in 1680, writing to another and much freer translator:

\footnotetext{
${ }^{5}$ In Tarvi 2004: 234.

${ }^{6}$ Le Ton beau de Marot (New York: Basic Books, 1997), 548, 268, 270, 269.
} 
That servile path thou nobly do'st decline,

Of tracing word by word and Line by Line. (EO III.13)

Nabokov knew how paradoxical it was for him to proclaim servility as a virtue, but in this one case he did it with glee.

Nabokov was also remarkable as a writer for his love of verbal pattern: "Lolita, light of my life, fire of my loins. My sin, my soul. Lo-lee-ta: the tip of the tongue taking a trip of three down the palate to tap, at three, on the teeth. Lo. Lee. $T a$." Yet he insisted that in translation it was meaning that counted, not pattern. When he translated the start of Lolita himself, he preserved the sense, not the sound of "Lolita, light of my life, fire of my loins": listen to this: "Lolita, svet moey zhizni, ogon' moikh chresel. Grekh moy, dusha moya." He wrote about a thousand poems, over nine hundred and ninety rhymed. In his longest and best poem, "Pale Fire," he launched an attack on what was then thought the best long poem in English, T.S. Eliot's Four Quartets, partly because, unlike Eliot, he saw such rich untapped opportunities in rhyme. Why did a poet who insisted on the virtues of rhyme insist that translating rhymed verse in rhymes was a vice and a crime?

A third paradox was the moral fervor with which he argued for unrhymed translations-and others argued for rhyme. Nabokov even associated rhymed translation with betrayal and with torture. Why?

In language, if you're a native speaker, you can know instantly and absolutely when something is said incorrectly. That can make the mistakes of a non-native speaker very funny to a native speaker: as Nabokov's hero poor Professor Pnin seems funny: although he speaks eloquently in his native Russian or his acquired French he cannot avoid blundering in the English he has to speak in American exile. He offers to pour people whisky and sodas but pronounces it "viscous and sawdust," which is a remarkably accurate fusion of a number of typical Russian mistakes. He at last is able to buy his first home, and he invites people not to a house-warming party but to a house-heating party. Language can instantly jar on us as wrong, quite wrong. For Hofstadter, and the defenders of rhymed verse, not having rhyme in the translation itself jars as wrong. For Nabokov, and the defenders of literalism, not having the exact sense jars and distorts. 
Let me explain Nabokov's principles of translation and his passion for accuracy in terms of the way he saw the world at large. He once told an interview he could define reality only

as a kind of gradual accumulation of information; and as specialization. If we take a lily, for instance, or any other kind of natural object, a lily is more real to a naturalist than it is to an ordinary person. But it is still more real to a botanist. And yet another stage of reality is reached with that botanist who is a specialist in lilies. You can get nearer and nearer, so to speak, to reality; but you never get near enough because reality is an infinite succession of steps, levels of perception, false bottoms, and hence unquenchable, unattainable. (SO 10-11)

Nabokov felt that a world as full and rich as ours offers endless rewards for curious minds. He writes of one of his characters, "He was a pessimist, and like all pessimists, ridiculously unobservant." The more we make the effort to understand the surprising particulars of our world, he thought, the more we take the effort to see the individuality of things, the more we can appreciate the world we find ourselves in. But it does take effort. ${ }^{7}$

Contrast that attitude with that of translators who don't think particulars matter to the original poet or the poet's audience. ${ }^{8}$ In one of his notes to Eugene Onegin, Nabokov writes:

Whatever accuracy I have achieved in this stanza, I owe to the ruthless and triumphant elimination of rhyme. Its conservation was one of the things that led a predecessor of mine (Miss Deutsch, 1936) to string the following versicles supposedly representing the passage given above (XXVIII: 1-8):

Tatyana might be found romancing Upon her balcony alone

\footnotetext{
${ }^{7}$ [[Nabokov has one bizarre comparing the prodigious effort of trying to translate Shakespeare exactly
} to

someone, having seen a certain oak tree (further called Individual T) growing in a certain land and casting its own unique shadow on the green and brown ground, [and proceeding] to erect in his garden a prodigiously intricate piece of machinery which in itself was as unlike that or any other tree as the translator's inspiration and language were unlike those of the original author, but which, by means of ingenious combinations of parts, light effects, breezeengendering machines, would, when completed, cast a shadow exactly similar to that of Individual $\mathrm{T}$ - the same outline, changing in the same manner, with the same double and single spots of suns rippling in the same position, at the same hour of day. (BS 119-20)

]]

${ }^{8}$ [[image of grotesquely complicated effort on the part of the translator he has invented with what Nabokov could expose as the ignorance of real translators:]] 
Just as the stars had left dancing,

When dawn's first day had barely shown;

When the cool messenger of morning,

The wind, would enter, gently warning

That day would soon be on the march,

And wake the birds in beech and larch.

The sins of omission are too numerous to be noted; but there is one sin of commission that is typical of this particular version of $E O$, in which all kinds of images and details are bountifully added to Pushkin. What, for instance, are those birds and trees doing here: "And wake the birds in beech and larch"? Why this and not, for instance, "And take in words to bleach and starch" or any other kind of nonsense? The charming point is that beeches and larches, not being endemic in west central Russia, are the very last trees that Pushkin would imagine growing in the Larins' park. (EO II.286-87)

Nabokov believed we need to know our world or risk living in a fog of vagueness. He wrote to the French translator of his novel Pale Fire: "I come now to a chain of errors that, coming from you, astonish me. You tell me that according to Webster [Webster's great American dictionary, Nabokov's favourite] the hickory belongs to the walnut family. True, but you're confusing family and genus! Translating hickory by "noyer [walnut]" would be just as strange as translating chestnut by "hêtre [beech]" and oak by "marronier [chestnut]" because all three belong to the beech family, Fagaceae!) or as translating "chat [cat]" by tiger, and jaguar by "lynx" because all four are in the family Felidae!"9

\footnotetext{
${ }^{9}$ [ IIn the novel he wrote after Pale Fire, Ada, he has his precocious heroine translate for her French governess some lines from "Matin d'Octobre," by the nineteenth-century poet François Coppée. She shows the draft to her equally precocious brother and lover, Van:
}

Their fall is gentle. The woodchopper

Can tell, before they reach the mud,

The oak tree by its leaf of copper,

The maple by its leaf of blood.

Here's the French original:

Leur chute est lente. On peut les suivre

Du regard en reconnaissant

Le chêne à sa feuille de cuivre

L'érable à sa feuille de sang.

Literally, this would be:

Their fall is gentle. You can follow them

With your gaze, recognizing

The oak tree by its leaf of copper,

The maple by its leaf of blood. 
Let's watch Nabokov's own care with trees in one line of Eugene Onegin. And as he discusses the problem of translating the name of a single tree, I'd like you to imagine that the first of these two trees means as much to a Russian as a pohutukawa does to a New Zealander, that it has overtones to a Russian as important as the color and shapes of the leaves and flowers and terrestrial and aerial roots of the pohutukawa, and its evocation of beaches and Christmas blossom and endless summer holidays. Imagine you want to translate into Russian or Japanese a famous New Zealand poem that just mentions in passing, because that's all it needs to do, a pohutukawa, for which there's not even a word waiting in Russian or Japanese, and to convey all its associations.

The line Nabokov would like to translate is Pod sén' cheryómuh i akátsiy:

Beneath the cheryomuhas and the acacias:

The bower alluded to in the line under discussion is formed by two kinds of shrubs or trees. Do their mere names suggest anything to the Russian reader? We all know that the popular name of a plant may strike the imagination differently in different languages; its stress may be on color in one country and on structure in another; it may have beautiful classical connotations; it maybe redolent of unbelievable Floridas; it may contain a honeydrop as residue of the cumulative romantic sense bestowed upon it by generations of elegiasts; it may be, in floral disguise, a plaque commemorating (like the dahlia) the name of an old botanist or (like the camellia) that of a roving Jesuit back from Luzon. The words cheryómuh and akátsiy (both fem. gen. pl.) convey to the Russian mind two flowery masses and what may be termed a stylized blend of aromas. . . I do not think that it is the translator's duty to trouble much about

Van, being also a genius, remembers the original French lines, and quotes them back at her: "Leur chute est lente," said Van, "on peut les suivre du regard en reconnaissant-that paraphrastic touch of 'chopper' and 'mud' is, of course, pure Lowden (minor poet and translator, 1815-1895). Betraying the first half of the stanza to save the second is rather like that Russian nobleman who chucked his coachman to the wolves, and then fell out of his sleigh."

Nabokov has given Ada a brilliant mistranslation. To rhyme with copper, she has imagined a woodchopper standing in the woods, watching the autumn leaves fall. But what seems to her like a good find turns out to be a disaster, since it conjures up, not the hush of an autumn morning with only the leaves falling, but great trees crashing down.

Four years later Van quotes to their father-who doesn't yet know they are lovers-what he claims will be Ada's translation. In fact, he has silently corrected her blunder with a much better and much less dangerous find than her woodchopper:

"Their fall is gentle. The leavesdropper

Can follow each of them and know

The oak tree by its leaf of copper,

The maple by its blood-red glow."

Ada utters an indignant "Pah!" because her brother is an even better show-off than her.

That's Nabokov playing around with trees and translations (although this particular mistranslation links with another that points ahead to a tragedy that results from Van and Ada's incestuous love).]] 
the rendering of associations in his text, but he should explain them in his notes. It is certainly a pity that the euphonious French name of some plant, say, l'alidore (to invent one), with its evocation of love philtres and auroral mists, should become in England (hog's wart) because of the singular form of its flowers), or cotton bud (because of the texture of its young leaves), or parson's button (allusion untraceable). But unless a name of that kind might puzzle or mislead the reader by referring to a dozen different plants (and then the Latin specific name should be given), the translator is entitled to use any available term as long as it is exact.

Nabokov goes on to explain that the Russian cheryomuha is the racemose oldworld bird cherry, Padus racemosa.

The Russian word, with its fluffy and dreamy syllables, admirably suits this beautiful tree, distinguished by its long racemes of flowers, giving the whole of it, when in bloom, a gentle pendulous appearance. A common woodland plant in Russia it is equally at home among the riverside alders and on the pine barren; its creamy-white, musky, Maytime bloom is associated in Russian hearts with the poetical emotions of youth.

And because it doesn't have an exact English term, he proposes a new one, racemosa, which matches the technical species name, and will be both exact and have the right romantic sound. When this word came up for discussion in a Nabokov listserv, a Russian naturalist and poet told everybody to look up the tree on Wikipedia, then to go to a good botanical garden, like Kew Gardens in the UK, or St. Louis in the US, to sniff its special aroma. He adds: "One cannot feel Russian literature in full ... without seeing and smelling racemosa." He attached a picture and wished he could also attach an olfactory file for sniff downloads.

Nabokov thinks that in translating a major masterpiece, like Eugene Onegin, a translator should not only translate literally, which will take away the magic, but should also try to do everything else to conjure up the spell of the original. He first intended to have the entire Russian text transliterated from Cyrillic into the Roman alphabet, with stress marks added; but it took him so long to get a publisher to accept even a four-volume version that he didn't insist on the five-volume version this would have taken. He writes two brilliant stanzas in English in the stanza form that Pushkin invented for Evgeniy Onegin, "On Translating Eugene Onegin," two sharply contrasting stanzas just to give some of the effect of the versatility of tone and speed Pushkin's stanzas could have, to give English readers some flavor of the flair of a Eugene Onegin stanza. He describes in detail the most spectacular sound effects in 
particular passages of the Russian. And he writes a ninety-page appendix comparing English and Russian metre, so that we can understand in principle the differences between English and Russian rhythms and English and Russian variations on those standard rhythms. And in his copious notes he explains the associations that surround the raw words, the facts that Pushkin's original audience could have taken for granted.

Nabokov's not only struggling to find and even create if need be the one exact English word that will refer to cheryomuha, and to what the word conjures up for Pushkin's natural immediate audience, could not be further from Babette Deutsch inventing beeches and larches, for the sake of a rhyme, in a stanza where Pushkin doesn't mention any trees at all, and certainly wouldn't have planted those ones in that ground.

But there's more to literature than trees. The title of my talk is Precision and Passion. Let's see how a little effort toward precision can unlock the passion in Pushkin.

Pushkin has a special place in the hearts of all Russian lovers of literature. He has a particularly special place for Nabokov, throughout his Russian work and throughout his efforts as an English writer to make Pushkin known. Pushkin is also a byword for the untranslatability of poetic greatness: unquestioned in his preeminence within his native land, yet long almost unrecognized within any other. Flaubert, one of the brightest stars in Nabokov's own literary sky, famously remarked to his friend Turgenev: "He is flat, your poet."

Nabokov translated one of Pushkin's great love lyrics, "Ya vas lyubíl" ("I loved you") three times, in three different ways: in an awkward verse translation, in 1929, and in a literal translation and a lexical (word for word) translation, accompanied by a stress-marked transliteration and a note, about twenty years later. None of these quite works (the lexical is not even meant to work, merely to supply the crudest crib), none of these can quite convince the English reader that this is one of the great love lyrics — one of the great lyrics — in any language.

Yet Nabokov is not alone. For the bicentennial of Pushkin's birth his greatgreat-great-granddaughter, who was chairman of the British Pushkin Bicentennial Trust, asked herself "How do you convince the English-speaking public that Pushkin's genius is as great as the Russians claim?" She answered herself: "what about asking a number of our best living poets to 'translate' some Pushkin poems, or 
rather to make 'poems' out of Pushkin translations?" She commissioned poets of the stature of Ted Hughes, Seamus Heaney, and our own Allen Curnow, author of a spectacular pohutukawa poem. Carol Ann Duffy, now the English poet laureate, took "Ya vas lyubíl":

I loved you once. If love is fire, then embers smoulder in the ashes of this heart.

Don't be afraid. Don't worry. Don't remember.

I do not want you sad now we're apart.

I loved you without language, without hope, now mad with jealousy, now insecure.

I loved you once so purely, so completely,

I know who loves you next can't love you more.

Duffy is a fine poet, but I suspect few will think this one of literature's great lyrics — not that she is not as successful as other poets in After Pushkin. ${ }^{10}$ What is it that makes Pushkin's poem great?

I offer a plain translation into lineated prose:

I loved you; love still, perhaps,

In my heart has not quite gone out;

But let it trouble you no more;

I do not want to sadden you in any way.

I loved you wordlessly, hopelessly,

Now by timidity, now by jealousy oppressed;

I loved you so sincerely, so tenderly,

As God grant you may be loved by someone else.

The poem starts with what might seem banal, "Ya vas lyubil," except that it is in the past, and that gives it its special angle. As Pushkin treats of the near-universal experience of having fallen out of love, he gradually moves from the not unusual the change from present love to near-past, the after-shock of feeling, the shift from desire to tender interest and concern - to the unexpected closing combination, the affirmation of the past love in the penultimate line, "I loved you so sincerely, so tenderly," then the selfless generosity of the last line, the hope that she will be loved again as well as he has loved her, that in its very lack of selfishness confirms the purity of the love he had and in some sense still has.

${ }^{10}$ Elaine Feinstein, ed., After Pushkin (London: Folio Society, 1999). 
Where Duffy's "who loves you next" almost implies a line-up of lovers, Pushkin offers a surprise, yet utter emotional rightness and inevitability. Where Duffy's line becomes a near-boast, emphasizing that the speaker's love is unsurpassable, Pushkin's speaker dismisses self to focus on and pray for his former love.

This is what Pushkin is like, again and again. He cuts directly to the core of a human feeling, in a way that makes it new and yet recognizably right and revelatory. He creates a complex emotional contour through swift suggestion, a scenario all the more imaginatively inviting because unconstrained by character and event. His expression seems effortless and elegant, but his attention and ours is all on the accuracy of the emotion. In this poem Pushkin allows just one shadow of one metaphor, in the verb in the second line, ugásla, which can mean "gone out" or "extinguished," where Duffy feels the need to embellish and poeticize the image into "If love is fire, then embers / smoulder in the ashes of this heart," with a pun on "heart" and "hearth." This is inventive translation, but it is not Pushkin's steady focus on feeling. Duffy's lines draw attention to the poet, to the play. In other moods Pushkin can himself be supremely playful, and playfully self-conscious, in his own fashion, but here he offers an emotional directness and a verbal restraint amid formal perfection that is alien to English poetry and that to Duffy feels too bald to leave unadorned.

With your attention now engaged, ready to slow down and savor this poem, I offer below Pushkin's own words, transliterated and stressed, with an italicized wordfor-word match in italics below (a "lexical translation" in Nabokov's terms) and my strictly literal translation below that.

What I will show on screen here conflates and adapts Nabokov's methods at their best. It follows his logic, from which even he, despite his hatred of compromise, ultimately backed off. I provide the Russian text, transliterated into the Roman alphabet and stress-marked, as Nabokov always did in his notes to Eugene Onegin, to ensure maximum accessibility for readers without Russian. ${ }^{11}$ I present the poem in interlinear form, with a translation, as Nabokov intended for Eugene Onegin in the mid-1950s, until the scale of the work made him think he would never find a

\footnotetext{
${ }^{11}$ (In fact, most unusually for a Russian, he hoped that Cyrillic script would be replace by Roman for writing Russian, since he saw it as a barrier between Russian literature and the rest of the world and Western culture and Russia [VNSY 329].)
} 
publisher to present it as he wanted. ${ }^{12}$ I draw on his lexical and literal translations to provide a plain prose translation, and I also add between the two a pure lexical translation such as he often used to clarify the exact Russian word for each English equivalent. Nabokov opposed "readable" translations, translations without effort that can make us think we're in touch with the original but in fact become opaque, distorting, inadequate pseudo-equivalents, more a reflection of our own ignorance than a means of seeing through to the original. But he felt that a reader without the source language who was ready to make the effort we always need to make to understand our world could see through to the original and its own irreplaceable magic.

Please take your time.

Ya vas lyubíl: lyubóv' eshchyó, bït' mózhet, I you loved: love yet, be may,

I loved you; love, perhaps, has not yet

V dushé moéy ugásla ne sovsém;

In soul my gone-out not altogether

Quite gone out in my heart;

No pust' oná vas ból'she ne trevózhit;

But let it [my love] you more not trouble;

But let it trouble you no more;

Ya ne hochú pechálit' vas nichém.

I not want to-sadden you in-any-way

I do not want to sadden you in any way.

Ya vas lyubíl bezmólvno, beznadézhno,

I you loved wordlessly, hopelessly.

I loved you wordlessly, hopelessly,

To róbost'yu, to révnost'yu tomím;

Now by-timidity, now by-jealousy tormented.

Now by shyness, now by jealousy oppressed;

Ya vas lyubíl tak ískrenno, tak nézhno, I you loved so sincerely, so tenderly,

I loved you so sincerely, so tenderly,

Kak day vam Bog lyubímoy bït' drugím.

As give you God loved to-be by-another.

As God grant you may be loved by someone else.

${ }^{12}$ VNAY 329, 336 
Nabokov perceptively notes the sound-link between lyubim and drugim in the last line, which makes the inevitability and the surprise both greater. Drugím, coming last, rhyming quietly and expectedly with tomím but also happening to echo the lyubimoy it is linked so closely to in sense, sets off the whole poem's explosive emotional charge in its final word, without resorting to anything conventionally "poetic." And a Russian might well expect a short poem beginning Ya vas lyubíl, "I loved you," and leading up to a rhyme with tomím to end with the word lyubim, "loved" or "beloved"; instead it ends with drugím, "by another" (by another male) as if to compress the difference between the $y a$, the "I" who used to love you in the poem's first word and this drugím, this "other" in the poem's last word, who perhaps will love you so well. ${ }^{13}$

Nabokov first tried to translate this poem, uncharacteristically, in 1929, when he was developing as a Russian writer, and almost always translating into rather than from Russian. his rhymes are trite (fashion-passion, true-you) and the whole poem compliantly follows tired English verse conventions. By the 1940s, Nabokov's verse translations into English were far more assured, and often superb. By the 1950s, he had committed himself to literalism, but sometimes with uneasy compromises, if not for the sake of rhyme, for the sake of rhythm. In the case of Ya vas lyubíl, his "lexical" translation often seems closer than the literal translation not only to Pushkin's words but to his power.

Nabokov says he regularly felt the urge to tinker with his translations, and he may well have continued to do so here, had he prepared his own Verse and Versions. But the difficulties he himself had translating his favorite Russian poet — difficulties he expresses eloquently and ironically in his own voice - are as interesting as, and deliberately more challenging than, his successes. Nabokov uncompromisingly translates the second line of Ya vas lyubíl as "not quite extinguished in my soul." I rendered it as "in my heart has not quite gone out." In Russian, dushá, "soul," is far more common than its English equivalent and covers much of the territory of "heart" as the conventional seat of the emotions. Nabokov, in refusing to compromise on

\footnotetext{
${ }^{13}$ Alexander Zholkovsky, “'Ya vas lyubil ... ' Pushkina: invarianty i struktura” (“Pushkin's 'I loved you ... ': Invariants and Structure," http://www.usc.edu/dept/las/sll/rus/ess/bib21.htm.
} 
"soul," points to a difference between Russian and English that lies at the core of the difference between an English speaker's and a Russian's sense of self and other, life and death.

You've already heard that Pushkin famously compared translators to horses changed at the posthouses of civilization. In his earlier and more accessible rhymed translations, Nabokov makes us feel the posthorses have arrived, that we are meeting Pushkin, Lermontov, Tyutchev or Hodasevich almost face to face. In his later work, translation is not the illusion of arrival, but the start of a journey, glimpses of the destination, but also of the bracing rigors of the intervening terrain. Through the contrasting strategies that we showcase in Verse and Versions, and through the special methods of Eugene Onegin, Nabokov will continue to prod English-speaking readers into persisting on our journey toward the peaks of Russian poetry. 